\title{
CORE Curriculum and Students Perceptions: Approach to Curriculum Review
}

\author{
Ali M. Alghazo, Member, IACSIT
}

\begin{abstract}
A quantitative study addressing student's perceptions of three higher education institutions CORE curriculum within the kingdom of Saudi Arabia. The study utilized survey methodology to collect the perceptions of students across all four levels of freshman, sophomore, junior, and senior students. The data collected was analyzed using percentages for descriptive statistics and T-test for identifying relationships between the dependent and independent variables, the strength of the relationships was determined using (phi) since the variable were all categorical. The literature review of the following study will cover the Role of CORE curriculum in post-secondary education. The frame work of the current study is that the students' perception of their university curriculum affects the effectiveness of the learning process, and is to be considered in universities curriculum reviews. The major findings of the study show that students confidence levels with their CORE curriculum is greater than that of the overall curriculum, English courses ranked first in confidence level followed by Math courses and finally Natural science courses. The CORE curriculum model utilized affected students responses in relation to the level of agreement for the need to add new courses to the CORE curriculum, where students from universities apply the scholarly discourse model reported a higher agreement. Universities are recommended to provide additional resources to the Match course, and additional resources and knowledge base to the Natural Science courses. Limitations of study are the sampling strategies utilized in deciding the sample and the sample size. Recommendations of future research on students perceptions of universities curriculum and its importance in curriculum reviews, also a duplication of the following research is encouraged.
\end{abstract}

Index Terms-Curriculum review, CORE curriculum, workforce preparation.

\section{INTRODUCTION}

Post-secondary education institutions started out in the early 1920's for those privileged enough to gain higher education, while the rest of the populations settled for an elementary or secondary degree, which secured holders of such degrees with a job. The purpose of education has always been one and the same, to secure high wage employment. However, with the spread of post-secondary education, having a bachelor's degree alone no longer ensures high wage employment [1].

The debate of degree plans within post-secondary education institutions has always been fueled with the benefits gained for graduating students, many advocates of

Manuscript received December 3, 2013; revised February 5, 2014.

Ali M. Alghazo is with the Education and Development from Southern Illinois University at Carbondale, Kingdom of Saudi Arabia (e-mail: dr.alialghazo@gmail.com). different philosophical point of views arguing the nature, number and content of courses required to help students succeed in life after graduation. One widely argued part of most university degree plans is the CORE (General Education) university requirements, the debates have relied on many factors and arguments, however the students views and perspectives on the necessity of these courses has not been fully addressed.

The purpose of the study is to investigate student's perspectives on the importance of the CORE (General Education) curriculum, and to identify any differences in student perspective towards the CORE curriculum Models used, between the scholarly discourse model and the effective citizen model.

\section{LITERATURE REVIEW}

CORE curriculum (general education) freshman courses are designed to provide students with a general knowledge and to enhance their knowledge in cultural, linguistic knowledge and to advance their competency level in critical thinking, problem solving, written and oral communication skills, [2]. The universities involved in the current study all have a department of general education studies, all departments share courses such as Math, Physics, Chemistry, English writing, Arabic and Islamic Studies, physical Education and social science electives, however one university stands out with courses that are clear in the purpose of preparing students for the required skills of the $21^{\text {st }}$ century. Liberal arts education is of a rich history that goes back to ancient societies such as the Romans and the Greek, liberal arts education that poses a need where all scholars regardless of major should be knowledgeable is agreed upon, however what courses or disciplines constitute the requirements of need has changed at different times throughout history [3]. This explains the variations found within the CORE curriculum of the three universities that took part of the following study. A study by Newton,[4] highlights three models utilized for CORE curriculums; the great books model, the model suggest the study of great books of the past is best for establishing a general education base in students, the question of what books are to be considered as a great book is yet debated and not very well defined, the scholarly discourse model, the model suggests the study of the knowledge of the latest breakthroughs and knowledge across different disciplines, which disciplines are to be considered is still an area to be debated and justified, the third model is the effective citizen model, [5] the model provides a realistic and practical view of the function of the CORE (general education courses) where it identifies 
disciplines and competencies that are best to help students succeed in the $21^{\text {st }}$ century, a key aspect of this model is Critical Thinking and Problem Solving. A recent study by the Gallup Organization identified the workplace competencies most needed today: skills in dealing with people, critical thinking skills (creative thinking, decision-making, problem-solving, reading speed and comprehension, basic use of computers, public speaking, writing ability, and basic mathematics [6].

From reviewing the CORE curriculum of the three universities participating in the study it was found that one university fully implements the effective citizen model, while the remaining two universities are more towards the scholarly discourse model.

A debate behind closed doors within universities discussing the benefits and actual need of CORE general education courses is ongoing, specially that general education courses are consuming more than one third of academic degree programs, colleges are striving to minimize general education courses required in favor of technical major specific courses, while on the other hand CORE curriculum advocates argue for the need of each and every general education course, research has provided evidence that general education courses are a necessity for students success, [7], [8]. The following study reports on the importance of CORE (general Education) curriculum from the students perspective, the results of the following study will assist university administrators in having a more holistic view of the importance of the CORE curriculum, as administration usually out past students point of view and perspectives towards their own education. Also, the results of the following study will identify any differences in student perspective towards the CORE curriculum Models used, between the scholarly discourse model and the effective citizen model.

\section{Methodology}

The study utilized a survey methodology, where a survey was distributed across three universities within the kingdom of Saudi Arabia, the selection of the three universities was that of convenience where only universities with close proximity to the researcher were selected. The population of the study was all students from all three universities, however a convenient sample of 346 students from all three universities was selected; 120 students from University A, 131 students from university B, and 95 students from University $\mathrm{C}$. The survey instrument consisted of 8 questions, 2 demographic question and 6 questions addressing the topic of study. Descriptive analysis was used to analyze the results as well as chi-square test of independence to test for relationships amongst variables. The strength of the relationship was determined using (phi). A review of the
CORE curriculum identified two models being utilized by the three universities; one university is utilizing the effective citizen model and two universities are utilizing the scholarly discourse model.

\section{RESUlTS AND DisCUSSION}

Demographic analysis of the results identified the following representation of the respondents in relation to their university and at what level they are within their education; Freshman, Sophomore, Junior, or Senior. The universities were coded as University A, B, and C, however there is no specific order to the universities, the names of the universities are kept anonymous. Table I and Table II provide the demographics breakdown of the sample.

TABLE I: UNIVERSITY DISTRIBUTION

\begin{tabular}{ccc}
\multicolumn{3}{c}{ TABLE I: UNIVERSITY DISTRIBUTION } \\
\hline University & Number & Percentage \\
\hline University A & 120 & $35 \%$ \\
\hline University B & 131 & $38 \%$ \\
\hline University C & 95 & $27 \%$ \\
\hline Total & 346 & $100 \%$ \\
\hline & TABLE II: STUDENTS LEVEL \\
\hline Students ${ }^{\text {Level }}$ & Amount & Percentage \\
\hline Freshman & 171 & $49 \%$ \\
\hline Sophomore & 65 & $19 \%$ \\
\hline Junior & 85 & $25 \%$ \\
\hline Senior & 25 & $7 \%$ \\
\hline Total & 346 & $100 \%$
\end{tabular}

The relationship between University and students' confidence in the overall curriculum, Math courses, English course, Science courses, the need for adding courses, and whether the curriculum is preparing students for the workforce was investigated using the chi-square test of independence, see Table III. The null hypothesis of the following study is that variable University and student's confidence are independent.

The results of the chi-square test of independence showed that on all questions there is a dependent relationship with the variable university.

The strength of the relationship was tested using the phi statistical test.

Table IV represents the demographics of the sample, results show that university A was represented with a total of $35 \%$ percent of that we found that $54 \%$ are freshman, $13 \%$ are sophomores, $25 \%$ are juniors and $8 \%$ are seniors. University B was represented with $38 \%$ from which $50 \%$ are freshman, $15 \%$ are sophomores, $27 \%$ are juniors and $8 \%$ are seniors. University C was represented with $27 \%$ of the sample from which $42 \%$ are freshman, $32 \%$ are sophomores, $21 \%$ are juniors and $5 \%$ are seniors.

TABLE III: PEARSON CHI-SQUARE TEST OF INDEPENDENCE

\begin{tabular}{|c|c|c|c|c|c|c|c|}
\hline & & Overall & Math & English & Science & Adding & Work \\
\hline \multirow{3}{*}{ 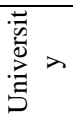 } & Chi-square & 309.101 & 281.840 & 346.000 & 392.819 & 522.420 & 75.694 \\
\hline & $\mathrm{df}$ & 4 & 4 & 4 & 6 & 6 & 4 \\
\hline & Sig. & $.000^{*}, \mathrm{~b}$ & $.000^{*, b}$ & $.000^{*, \mathrm{~b}}$ & $.000^{*, \mathrm{~b}}$ & $.000^{*, b}$ & $.000^{*, \mathrm{~b}}$ \\
\hline
\end{tabular}

Results are based on nonempty rows and columns in each innermost sub table.

*. The Chi-square statistic is significant at the .05 level. 
TABLE IV: CROSS TABLE UNIVERSITY AND LEVEL

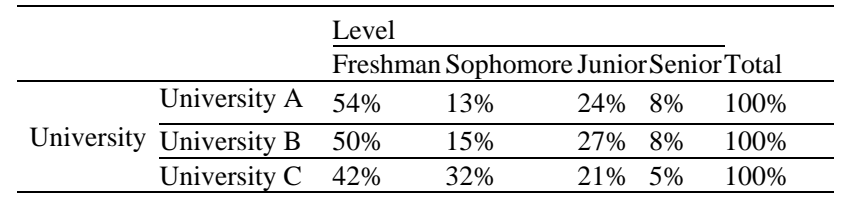

Participants were asked to rate their confidence in the overall curriculum of their universities, the results show that the majority of the sample $39 \%$ are confident with the overall curriculum where $26 \%$ were strongly confident, and $35 \%$ were neutral on this question, see Table V.

Participants were asked to rate their confidence in the overall curriculum of their universities, the results show that the majority of the sample $39 \%$ are confident with the overall curriculum where $26 \%$ were strongly confident, and $35 \%$ were neutral on this question, see Table V.

TABLE V (A): CONFIDENCE IN OVERALL UNIVERSITY CURRICULUM

\begin{tabular}{lll}
\hline & Amount & Percentage \\
\hline Very Confident & 91 & $26 \%$ \\
\hline Confident & 135 & $39 \%$ \\
\hline Natural & 120 & $35 \%$ \\
\hline Not Confident & 0 & $0 \%$ \\
\hline Very Not Confident & 0 & $0 \%$ \\
\hline Total & 346 & $100 \%$ \\
\hline
\end{tabular}

When investigating this question further we find that students from University B show the highest confidence level with their overall curriculum where $69 \%$ are very confident and $23 \%$ are confident, followed by University A where students are $75 \%$ confident and $25 \%$ are neutral, however University $\mathrm{C}$ students show a very low confidence level with only $16 \%$ are confident and the remaining $84 \%$ are neutral, see Table V.

TABLE V (B): CROSS TABLE UNIVERSITY AND OVERALL CONFIDENCE

\begin{tabular}{lccccc}
\hline & \multicolumn{2}{c}{ Very Confident } & Confident & \multicolumn{2}{c}{ Neutral } \\
\hline \multirow{2}{*}{ University } & University A & $0 \%$ & $75 \%$ & $25 \%$ & $100 \%$ \\
\cline { 2 - 6 } & University B & $69 \%$ & $23 \%$ & $8 \%$ & $100 \%$ \\
\cline { 2 - 7 } & University C & 0 & $16 \%$ & $84 \%$ & $100 \%$ \\
\hline
\end{tabular}

TABLE VI (A): CONFIDENCE IN MATH

\begin{tabular}{lll}
\hline & Amount & Percentage \\
\hline Strongly Agree & 210 & $61 \%$ \\
\hline Agree & 35 & $10 \%$ \\
\hline Natural & 101 & $29 \%$ \\
\hline Disagree & 0 & $0 \%$ \\
\hline Strongly Disagree & 0 & $0 \%$ \\
\hline Total & 346 & $100 \%$ \\
\hline
\end{tabular}

TABLE VI (B): CROSS TABLE UNIVERSITY AND MATH

\begin{tabular}{lllll}
\multicolumn{4}{c}{ TABLE VI (B): CROSS TABLE UNIVERSITY AND MATH } \\
\hline Math \\
\hline Very Confident & \multicolumn{4}{c}{ Confident Neutral Total } \\
\hline University University A & $83 \%$ & $17 \%$ & $0 \%$ & $100 \%$ \\
\hline University B & $84 \%$ & $8 \%$ & $8 \%$ & $100 \%$ \\
\cline { 2 - 5 } University C & 0 & $5 \%$ & $95 \%$ & $100 \%$ \\
\hline$P H I=.903$ & & & &
\end{tabular}

TABLE VIII (B): CROSS TABLE UNIVERSITY AND SCIENCE COURSES

\begin{tabular}{|c|c|c|c|c|c|c|}
\hline & & \multicolumn{4}{|l|}{ Science } & \multirow[b]{2}{*}{ Total } \\
\hline & & Very Confident & Confident & Neutral & Not Confident & \\
\hline \multirow{3}{*}{ University } & University A & $67 \%$ & $33 \%$ & 0 & 0 & $100 \%$ \\
\hline & University B & $100 \%$ & 0 & 0 & 0 & $100 \%$ \\
\hline & University C & $5 \%$ & 0 & $21 \%$ & $74 \%$ & $100 \%$ \\
\hline
\end{tabular}

PHI=1.06

Table IX shows the results of the sample when asked for the need to add new courses to the CORE curriculum within
Table VI shows the results of the sample when asked to state their level of confidence in Math courses, again it was found that $61 \%$ were very confident, and $10 \%$ are confident, while $29 \%$ are neutral. Further investigation showed that University B has the highest confidence $84 \%$ very confident while $8 \%$ reported confident and $8 \%$ neutral. University A $83 \%$ reported very confident, and $17 \%$ confident, while University C, 5\% confident and 95\% neutral see Table VI.

Table VII shows the results of the sample when asked about their confidence level in the English courses they are provided at their school, $73 \%$ of the sample is very confident in their English courses, and 25\% reported that they are confident. At further investigation, it was found that University A showed $100 \%$ very confident, and University B showed $100 \%$ very confident, while University C reported $89 \%$ confident and $11 \%$ neutral, see Table VII.

\begin{tabular}{lll}
\multicolumn{3}{l}{ TABLE VII (A): CONFIDENCE IN ENGLISH } \\
\hline & Amount & Percentage \\
\hline Strongly Agree & 251 & $72.54 \%$ \\
\hline Agree & 85 & $24.57 \%$ \\
\hline Natural & 10 & $2.89 \%$ \\
\hline Disagree & 0 & $0 \%$ \\
\hline Strongly Disagree & 0 & $0 \%$ \\
\hline Total & 346 & $100 \%$ \\
\hline
\end{tabular}

\begin{tabular}{|c|c|c|c|c|c|}
\hline & & \multicolumn{3}{|l|}{ English } & \multirow[b]{2}{*}{ Total } \\
\hline & & Very Confident & Confident & Neutral & \\
\hline \multirow{3}{*}{ University } & University A & $100 \%$ & 0 & 0 & 120 \\
\hline & University B & $100 \%$ & 0 & 0 & 131 \\
\hline & University $\mathrm{C}$ & 0 & $89 \%$ & $11 \%$ & 95 \\
\hline
\end{tabular}

\begin{tabular}{lll}
\multicolumn{3}{l}{ TABLE VIII (A): CONFIDENCE IN SCIENCE } \\
\hline & Amount & Percentage \\
\hline Strongly Agree & 216 & $62 \%$ \\
\hline Agree & 40 & $12 \%$ \\
\hline Natural & 20 & $6 \%$ \\
\hline Disagree & 70 & $20 \%$ \\
\hline Strongly Disagree & 0 & $0 \%$ \\
\hline Total & 346 & $100 \%$ \\
\hline
\end{tabular}

Table VIII shows the results of the sample when asked about their confidence level in the science courses offered in the CORE curriculum program, $62 \%$ reported very confident, $12 \%$ we confident, $6 \%$ neutral and $20 \%$ were not confident. Upon further investigation the results showed that University $\mathrm{B}$, reported $100 \%$ very confident, and University A reported $67 \%$ very confident, and $33 \%$ confident, while university C, reported 5\% very confident and $21 \%$ neutral and $74 \%$ reported not confident see Table VIII. 
their schools the sample showed that $31 \%$ strongly agreed, $3 \%$ agreed, $30 \%$ were neutral and $36 \%$ disagreed. Upon further investigation it was found that University B, reported $71 \%$ that strongly agreed with adding new courses, and $23 \%$ disagreed, University A reported $4 \%$ that strongly agreed, $8 \%$ agreed, and $88 \%$ were neutral on the matter. University $\mathrm{C}$ reported $100 \%$ disagree with adding new courses to their CORE curriculum, see Table IX.

TABLE IX (A): NEED TO ADD MORE COURSES

\begin{tabular}{lll}
\hline & Amount & Percentage \\
\hline Strongly Agree & 106 & $30.6 \%$ \\
\hline Agree & 10 & $2.9 \%$ \\
\hline Natural & 105 & $30.3 \%$ \\
\hline Disagree & 125 & $36.1 \%$ \\
\hline Strongly Disagree & 0 & $0 \%$ \\
\hline Total & 346 & $100 \%$ \\
\hline
\end{tabular}

TABLE IX (B): CROSS TABLE UNIVERSITY AND ADDING NEW COURSES

\begin{tabular}{llll}
\hline \multicolumn{3}{c}{ Adding } \\
\cline { 2 - 4 } Strongly AgreeAgreeNeutral \\
\hline \multirow{3}{*}{ University } & University A $4 \%$ & $8 \%$ & $88 \%$ \\
\cline { 2 - 5 } & University B $71 \%$ & 0 & 0 \\
\cline { 2 - 4 } & University C0 & 0 & 0 \\
\hline$P H I=1.22$ & & \\
\hline
\end{tabular}

TABLE X (A): CONFIDENCE IN COURSES PREPARATION FOR THE

\begin{tabular}{lll}
\multicolumn{3}{c}{ WORKFORCE } \\
\hline & Amount & Percentage \\
\hline Very Confident & 301 & $87 \%$ \\
\hline Confident & 15 & $4.3 \%$ \\
\hline Natural & 30 & $8.7 \%$ \\
\hline Not Confident & 0 & $0 \%$ \\
\hline Very Not confident & 0 & $0 \%$ \\
\hline Total & 346 & $100 \%$ \\
\hline
\end{tabular}

TABLE X (B): CROSS TABLE UNIVERSITY AND WORK PREPARATION

\begin{tabular}{llllll} 
& \multicolumn{3}{l}{ Work Preparation } & & \\
\cline { 2 - 6 } & & Very Confident & Confident & Neutral & Total \\
\hline \multirow{3}{*}{ University } & University A & $67 \%$ & $8 \%$ & $25 \%$ & $100 \%$ \\
\cline { 2 - 6 } & University B & $100 \%$ & 0 & 0 & $100 \%$ \\
\cline { 2 - 6 } & University C & $95 \%$ & $5 \%$ & 0 & $100 \%$ \\
\hline Total & 301 & 15 & 30 & 346 \\
\hline$P H I=.468$ & & & & & \\
\hline
\end{tabular}

Finally, Table $\mathrm{X}$ shows the results of the sample when asked to report their confidence level in that their university is preparing them to enter the workforce. The sample reported a $87 \%$ very confident, $4 \%$ confident, and $9 \%$ were neutral to the matter. Upon further investigation it was found that university $\mathrm{B}$, reported $100 \%$ confidence that their university was preparing them to the workforce, and university A, reported $67 \%$ very confident, $8 \%$ confident, and $25 \%$ were neutral on the matter. While university $\mathrm{C}$, reported $95 \%$ very confident, and $5 \%$ confident, see Table $\mathrm{X}$.

The results of the following study show that students within the kingdom of Saudi Arabia are fully aware and willing to take charge of their education. The study investigated the responses of students from three different universities in regards to the CORE curriculum. The CORE curriculum of the three universities were classified through a qualitative analysis into two models, the effective citizen model which was represented by university $A$, and the scholarly discourse model, which are represented in universities $\mathrm{B}$, and $\mathrm{C}$.

The fact that a significant difference in responses between university $\mathrm{C}$ and $\mathrm{B}$, clearly cannot be explained by the classified models, since they both are implementing the same model for their curriculum. However such a significant difference in responses imposes a need for further investigation to help determine the loss of confidence in students from university $\mathrm{C}$. nevertheless comparing students responses between university $\mathrm{A}$ and $\mathrm{B}$, we find that university B has managed to boost its students confidence in the universities overall curriculum. An analytical study of university B, would prove beneficial for higher education institutions to help increase students confidence. Students' responses to their math courses which is part of the CORE curriculum of all three universities indicate that a high percentage of students recognize that math courses are required to their success, and that university $\mathrm{A}$ and $\mathrm{B}$ have provided their student with required math courses however, university $\mathrm{C}$ student have reported a high percentage of neutral, this calls for further investigation, specially that both University B and C are utilizing the same curriculum model. English courses are seen as the bulk of most CORE general education curriculum at universities' within the kingdom of Saudi Arabia, universities tend to allocate good funding and resources for English courses within the CORE curriculum, all three universities provided students with international faculty, over 50\% are where English is their native language and all faculty members are graduates of countries where English is the native tongue, also student support services and teaching assistants are provided for students to assist with these courses. The results show that all universities had a close to $100 \%$ confidence level in regards to the English courses. Natural Science courses such as chemistry, physics, and biology are part of the CORE curriculum at all three universities, students responses to their confidence level shows that if to be ranked with English and Math courses the natural science courses will be ranked at the bottom of the confidence level within the study sample, reasons pertaining to this result might include that natural science courses are electives within the three universities degree plans, therefore students might not see the importance of such courses or its relevance to their success in their future careers. However it is highly noted that universities should provide students with the support needed, and knowledge to help them build more confidence in the natural sciences courses. One result of this study which has brought much controversy is students responses to whether there is a need to add courses to their current CORE curriculum, university B, where students have shown high confidence in their schools overall curriculum, math courses, English courses, and science courses, reported the highest need for adding courses to their CORE curriculum. Reviewing the CORE curriculum of the university and comparing the other schools shed some light as to the high agreement level from the students, where the curriculum of university B focused on math science and language, yet it did not provide its students with any courses related to the $21^{\text {st }}$ century skill, such as communication skill, critical thinking and problem solving. Also, this question raised a high concern in regards to University $\mathrm{C}$, student responses provided a poor confidence level in regards to all questions, however $100 \%$ of the responses did not agree with adding new courses to the curriculum. The following result 
requires further investigation as the three universities were selected as a convenient sample, however all universities showed strong similarities in regards to the CORE curriculum provided to the students. Finally students reported on whether their universities are preparing them for the workforce, and universities $\mathrm{B}$ and $\mathrm{C}$ reported high confidence levels, while university A showed that even though a high percentage of student do show confidence in regards to this question there is a noticeable percentage that was unable to determine the strengths of their confidence.

\section{CONCLUSION}

The major findings of the following study show that student's perceptions of their universities overall curriculum is less than their confidence level with their CORE general education courses. Students have reported very high confidence levels in regards to their CORE general education courses, where English courses have received the highest confident levels followed by math courses and finally with the natural science courses.

The curriculum model utilized for the CORE curriculum did not seem to show much of a difference in student's confidence level responses; however it has showed a significant difference in student's perception of the need for adding courses to the CORE curriculum program. As we can see from the results students from the universities utilizing the scholarly discourse model reported a greater need for adding new courses.

Universities are recommended to provide students with additional resources and more knowledge in regards to the natural science courses. Universities should try to apply the same practice that is utilized for the English courses to the Math courses, and apply practices utilized for both English and Math courses to the natural sciences courses.

The following study suggests more research to be conducted on student's perception of their curriculum and encourages universities to consider the results of such studies in their curriculum reform initiatives. Conducting the following study on a greater sample will provide a clearer description of the relationship between curriculum models and its effects on students perceptions of the courses provided. Limitations of the following study rest in the convenience of the sampling method, the number of respondents to the survey, and lack of public information in regards to universities curriculum development initiatives.

\section{REFERENCES}

[1] K. C. Gray and L. H. Edwin, Workforce Education: The Basics, Allyn and Bacon, 1998.

[2] E. A. Jones, L. M. Hoffman, G. Ratcliff, S. Tibbets, and B. A. Click, Essential Skills in Writing, Speech and Listening, and Critical Thinking for College Graduates: Perspectives of Faculty, Employers, and Policymakers, University Park: Pennsylvania State University Press, 1994.

[3] B. A. Kimball, Orators and Philosophers: A History of The Idea of Liberal Education, Expanded Edition, New York: College Entrance Examination Board, 1995.

[4] R. R. Newton, "Tensions and models in general education planning," Journal of General Education, vol. 49, no. 3, pp. 165-81, 2000.

[5] B. Bourke, J. N. Bray, and C. C. Horton, "Approaches to the CORE curriculum: An exploratory study of the top liberal arts and doctoral-granting universities," Journal of General Education JGE, vol. 58, no. 4, pp. 219-240, 2009.

[6] L. Lyons, "Which skills hold the secret to success at work?" The Gallup Organization, December 7, 2003.

[7] G. D. Kuh et al., Involving Colleges: Successful Approaches To Fostering Student Learning and Development Outside the Classroom, San Francisco: Jossey-Bass, 1991.

[8] G. D. Kuh et al., Student Success In College: Creating Conditions That Matter, San Francisco: Jossey-Bass, 2005.

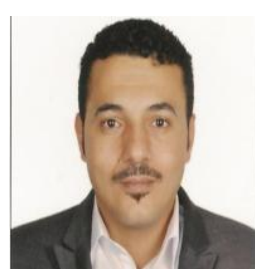

Ali M. Alghazo completed his $\mathrm{PhD}$ majoring in workforce (human resource) education and development from Southern Illinois University at Carbondale in 2008. He also holds two masters of science degrees. His first master's degree was completed in 2002 majoring in instructional technology \& instructional design. His second master's degree was completed in 2004 majoring in workforce (human resource) education and development. His bachelor degree was earned from Mu'tah University majoring in english language and literature.

Through his professional endeavor of pursuing a higher education, he has always kept the ultimate goal of excelling and mainly applying his learned knowledge and skills in the Middle East area which was the main reason of majoring in workforce (human resource) education and development Through his professional journey, he has worked as an online course manager for a full program in which first WEBCT and the later Blackboard were used to facilitate learning throughout the whole program. He has also worked on developing and implementing training material for the State of Illinois occupations and careers. Additionally, he gained experience in work legislation by working for the State of Illinois Workforce Investment Act. His research interests include technology integration, distance education, computer technology, instructional technology, instructional design, online curriculum development, assessment, teaching methods and materials, leadership, human resource development, international education, professional development, program evaluation, online training, and training program development. 